\title{
Periparturient dairy cows do not exhibit hepatic insulin resistance, yet adipose-specific insulin resistance occurs in cows prone to high weight loss
}

\author{
M. Zachut, ${ }^{*} \dagger$ H. Honig, ${ }^{*}$ S. Striem, $\ddagger$ Y. Zick, $\ddagger$ S. Boura-Halfon, $\ddagger^{1,2}$ and U. Moallem ${ }^{\star 2}$ \\ ${ }^{*}$ Department of Ruminant Science, Institute of Animal Sciences, Volcani Center, PO Box 6, Bet-Dagan, 50250, Israel \\ †Department of Animal Science, the Robert H. Smith Faculty of Agriculture, Food and Environmental Quality Sciences, \\ the Hebrew University of Jerusalem, Rehovot, 76100 , Israel \\ ‡Department of Molecular Cell Biology, The Weizmann Institute of Science, Rehovot, 76100, Israel
}

\section{ABSTRACT}

The periparturient period in dairy cows is associated with alterations in insulin action in peripheral tissues; however, the molecular mechanism underlying this process is not completely understood. The objective was to examine the response to a glucose tolerance test (GTT) and to analyze insulin signaling in liver and adipose tissues in pre- and postpartum dairy cows. Liver and adipose tissue biopsies were taken before and after GTT, at $17 \mathrm{~d}$ prepartum and again at 3 to $5 \mathrm{~d}$ postpartum from 8 high-yielding Israeli Holstein dairy cows. Glucose clearance rate after GTT was similar pre- and postpartum. Basal insulin concentrations and the insulin response to GTT were approximately 4 -fold higher prepartum than postpartum. In accordance, phosphorylation of the hepatic insulin receptor after GTT was higher prepartum than postpartum. Across periods, a positive correlation was observed between the basal and peak plasma insulin and phosphorylated insulin receptor after GTT in the liver. Hepatic phosphorylation of protein kinase B after GTT was elevated pre- and postpartum. Conversely, in adipose tissue, phosphorylation of protein kinase B after GTT pre- and postpartum was increased only in 4 out of 8 cows that lost less body weight postpartum. Our results demonstrate that hepatic insulin signaling is regulated by plasma insulin concentrations as part of the homeorhetic adjustments toward calving, and do not support a model of hepatic insulin resistance in periparturient cows. Nevertheless, we suggest that specific insulin resistance in adipose tissue occurs pre- and postpartum only in cows prone to high weight loss. The different responses among these cows imply that genetic background may affect insulin responsiveness in adipose tissue pre- and postpartum. Key words: peripartum insulin resistance, insulin receptor, protein kinase $\mathrm{B}$ (Akt)

Received September 10, 2012.

Accepted May 4, 2013.

${ }^{1}$ Corresponding author: s.boura-halfon@weizmann.ac.il

${ }^{2} \mathrm{~S}$. Boura-Halfon and U. Moallem contributed equally to this paper.

\section{INTRODUCTION}

The modern high-yielding dairy cow faces a great metabolic challenge during the peripartum period: a shift from a nonlactating, late-gestational, and lipogenic period to a state of tremendous energy demand for milk production. This results in massive lipolysis of adipose and catabolism of muscle tissues, as the cow is not able to consume sufficient nutrients to meet the energy requirements of the mammary gland (Bell and Bauman, 1997). In fact, the demand for glucose increases by 4 fold from late pregnancy to early lactation in dairy cows (Bell, 1995). Because the main source of glucose in ruminants is the conversion of propionate to glucose through hepatic gluconeogenesis, the liver adjusts to the high rate of gluconeogenesis postpartum by increasing the expression of key gluconeogenic enzymes such as pyruvate carboxylase (PC) and phosphoenolpyruvate carboxykinase (PEPCK; Graber et al., 2010).

Insulin plays a pivotal role in the physiological adjustments occurring around parturition in dairy cows (i.e., shifting from lipogenesis to lipolysis) while maintaining high glucose availability for the mammary gland. Bell and Bauman (1997) suggested that the marked reduction in whole-body glucose oxidation in newly parturient ruminants (Bauman and Elliot, 1983) implies reduced glucose use by peripheral tissues mediated by very low plasma insulin levels, and possibly tissue refractoriness to insulin. Insulin resistance is defined as a state in which the sensitivity of target cells to respond to ordinary levels of insulin is reduced (Boura-Halfon and Zick, 2009); therefore, ordinary levels of insulin fail to trigger its metabolic actions. It was concluded that the multiple adaptations from late pregnancy to lactation in dairy cows were at least partly mediated by development of insulin resistance in maternal peripheral tissues (Bell and Bauman, 1997). Indeed, in rats and in humans, it is well accepted that late pregnancy is characterized by a state of insulin resistance, which diminishes after parturition (Ryan et al., 1985; Sevillano et al., 2007).

Insulin action is initiated upon binding of insulin to its receptor, which activates the intrinsic tyrosine 
kinase activity of the insulin receptor (IR). Phosphorylation of Tyr residues of target proteins by the activated IR kinase triggers the propagation of 3 major signaling pathways: the phosphatidylinositol 3-kinase $(\mathrm{PI} 3 \mathrm{~K}) /$ protein kinase B (Akt); rat sarcoma/rapidly accelerated fibrosarcoma/extracellular signal-regulated kinase (Ras/Raf/ERK), and the $\mathrm{Cbl} / \mathrm{Cbl}$-associated protein (CAP) pathways, all promoting the metabolic and growth-promoting functions of insulin (Saltiel and Kahn, 2001).

Because the decline in insulin concentrations during the periparturient period as a homeorhetic regulation is evident, we hypothesized that this reduces insulin inhibition in lipolysis and gluconeogenesis. Consequently, an increase in lipids breakdown and glucose production occurs, while sustaining normal response to insulin in the target tissues. Therefore, the aim of the present work was to determine whether insulin signaling supports a mechanism of insulin resistance in the liver and adipose tissues during the periparturient period. To this end, we analyzed the effects of a glucose load on key elements along the insulin signaling pathway in pre- and postpartum dairy cows in biopsies of liver and adipose tissue.

\section{MATERIALS AND METHODS}

The experimental protocol of the study was approved by the Volcani Center Animal Care Committee and was conducted at the Volcani Center experimental farm in Bet Dagan, Israel. Eight high-yielding, $261 \pm$ 5 d pregnant, nonlactating Israeli Holstein dairy cows, which averaged $740 \pm 73 \mathrm{~kg}$ of live BW and average lactation number 4.6, participated in this study. Cows were group housed in covered loose pens with adjacent outside yards and fed ad libitum once per day at 1100 $\mathrm{h}$ with standard Israeli diets. The pre- and postpartum diets contained 1.46 and $1.77 \mathrm{Mcal}$ of $\mathrm{NE}_{\mathrm{L}} / \mathrm{kg}$ of DM and 13.2 and $16.6 \% \mathrm{CP}$, respectively (Table 1 ). After calving, cows were milked 3 times daily and milk production was recorded electronically (SAE Afikim, Kibbutz Afikim, Israel). One cow was excluded from analysis of milk production due to subclinical mastitis that led to culling at $60 \mathrm{~d}$ postpartum. The cows were weighed prepartum once per week, and postpartum were automatically weighed 3 times daily after each milking with a walking electronic scale (SAE Afikim). Body condition score was determined by a single technician on a scale of 1 to $5(1=$ lean, $5=$ obese $)$ at $261 \mathrm{~d}$ of pregnancy, and 3 to $5,14,28$, and $117 \pm 3 \mathrm{~d}$ postpartum.

Blood samples were collected 3 times weekly (Sunday, Tuesday, and Thursday) from $21 \mathrm{~d}$ before the expected calving until $21 \mathrm{~d}$ postpartum from the jugular vein into vacuum tubes containing lithium heparin (Becton Dickinson Systems, Cowley, UK). The blood samples were collected after morning milking at $0800 \mathrm{~h}$ and plasma was separated after centrifugation at 4,000 $\times g$ for $15 \mathrm{~min}$ and stored at $-32 \mathrm{C}$ pending analysis.

\section{Glucose Tolerance Test}

At late pregnancy $(261 \pm 5 \mathrm{~d}$ of pregnancy), 3 to $5 \mathrm{~d}$ postpartum, and at mid lactation $(117 \pm 3 \mathrm{~d}$ postpartum), cows received an intravenous glucose challenge after the morning milking. On the day before the glucose challenge, a catheter $(14 \mathrm{G} \times 13 \mathrm{~cm}$; Mila International, Erlanger, KY) was inserted into the jugular vein of each cow under local anesthesia to facilitate frequent blood collection. Food was withheld for $12 \mathrm{~h}$ before the glucose challenge and free access to water was maintained. Glucose was warmed to body temperature (38C) and administered intravenously as a $50 \%$ solution (Teva Medical Ltd., Ashdod, Israel) at $300 \mathrm{mg}$ of D-glucose $/ \mathrm{kg}$ of $\mathrm{BW}$ and at a constant rate by manually compressing the glucose pack. The infusion of glucose was completed within $3 \mathrm{~min}$. Blood samples were collected at 25 and $20 \mathrm{~min}$ before the start of the infusion, just before the infusion (time $t$ $=0$ ), every $5 \mathrm{~min}$ from $t=5$ to $t=45 \mathrm{~min}$ and then at 60 and $75 \mathrm{~min}$ after the infusion. Blood samples for insulin and NEFA analysis were collected into blood tubes containing lithium heparin (Becton Dickinson Systems). Additional blood samples for glucose analysis were collected into tubes containing lithium chloride and L-iodoacetate (BD Vacutainer; Belliver Industrial Estate, Plymouth, UK), and were immediately placed in ice. Blood samples were centrifuged within $30 \mathrm{~min}$ of collection at $4,000 \times g$ for $20 \mathrm{~min}$ and stored at $-32^{\circ} \mathrm{C}$ awaiting analysis. Two cows were excluded from analysis of glucose tolerance test (GTT) response prepartum; one due to technical failure of glucose infusion, and the other due to postponed calving. To obtain reference values of plasma glucose and insulin, GTT were performed in 4 of the cows at mid lactation (on average, $117 \pm 3 \mathrm{~d}$ postpartum) that were available at the farm at that time.

\section{Chemical Analysis}

Concentrations of plasma insulin were determined by RIA (Diagnostic Products Corp., Los Angeles, CA). The intra- and interassay coefficients of variation for insulin assay were 7.2 and $5.1 \%$, respectively. Plasma glucose was determined by a glucose reagent kit (Glucose UV $10 \times 50 \mathrm{~mL}$; Raichem, San Diego, CA). Plasma NEFA concentrations were determined by a kit (Wako NEFA C test kit; Wako Chemicals GmbH, Neuss, Germany). 
Table 1. Ingredients and chemical composition of diets during the dry period and lactation

\begin{tabular}{|c|c|c|}
\hline \multirow[b]{2}{*}{ Item } & \multicolumn{2}{|c|}{ Diet } \\
\hline & Dry cow & Lactating cow \\
\hline \multicolumn{3}{|l|}{ Ingredient, $\%$ of DM } \\
\hline Corn grain (ground) & 9.1 & 16.9 \\
\hline Barley grain (rolled) & 3.5 & 6.5 \\
\hline Wheat & 3.5 & 6.5 \\
\hline Rapeseed meal & 1.2 & 2.2 \\
\hline Soybean meal & 1.0 & 1.8 \\
\hline Sunflower meal & 2.4 & 4.5 \\
\hline Corn gluten feed & 7.0 & 12.9 \\
\hline Cottonseed & 1.1 & 2.0 \\
\hline Corn silage & 10.3 & 19.1 \\
\hline Dried distillers grain & 4.1 & 7.5 \\
\hline Soy molasses & 1.2 & 2.2 \\
\hline Oats hay & 51.8 & 11.1 \\
\hline Lucerne hay & 1.5 & 2.7 \\
\hline Calcium salts of FA & 0.7 & 1.2 \\
\hline Urea & 0.2 & 0.4 \\
\hline Calcium bicarbonate & 0.5 & 0.9 \\
\hline Salt & 0.4 & 0.8 \\
\hline Vitamins and minerals ${ }^{1}$ & 0.1 & 0.1 \\
\hline Limestone & 0.4 & 0.7 \\
\hline \multicolumn{3}{|c|}{ Chemical composition, $\%$ of DM } \\
\hline $\mathrm{CP}$ & 13.2 & 16.6 \\
\hline Crude $\mathrm{NDF}^{2}$ & 44.0 & 32.6 \\
\hline NDF (forage) ${ }^{3}$ & 36.8 & 19.4 \\
\hline Ether extract & 3.2 & 4.1 \\
\hline $\mathrm{Ca}$ & 0.6 & 0.9 \\
\hline $\mathrm{P}$ & 0.4 & 0.45 \\
\hline $\mathrm{NE}_{\mathrm{L}},{ }^{4} \mathrm{Mcal} / \mathrm{kg}$ & 1.46 & 1.77 \\
\hline
\end{tabular}

The intra and interassay coefficients of variation for NEFA assays were 7.1 and $6.3 \%$, respectively, and those for glucose assays were 2.8 and $2.3 \%$, respectively.

\section{Liver and Adipose Tissue Biopsies}

Liver and adipose tissue biopsies were taken from each cow at 2 time points: late pregnancy and early postpartum (261 $\pm 5 \mathrm{~d}$ of pregnancy and 3 to $5 \mathrm{~d}$ postpartum). At each time, 4 samples of liver and 4 adipose samples were taken before GTT, and then 4 additional liver and adipose samples were taken at 25 and $30 \mathrm{~min}$ after glucose infusion, respectively.

For the liver biopsy, the 11th intercostal space was shaved, sanitized with iodine scrub and $70 \%$ alcohol, and anesthetized with a 7 -mL subcutaneous injection of $2 \%$ lidocaine $\mathrm{HCl}$ (Esracain 2\%, $200 \mathrm{mg}$ per $10 \mathrm{~mL}$; Rafa Laboratories Ltd., Jerusalem, Israel). An incision of approximately $1 \mathrm{~cm}$ was made through the skin and the biopsy instrument (Bard Magnum; Bard Biopsy Systems, Tempe, AZ) with a $14 \mathrm{G} \times 20$-cm needle was used to pierce the intercostal space. The procedure was ultrasound guided (Aquila; Pie Medical Imaging BV, Maastricht, the Netherlands) and 4 liver samples (25 mg each) were taken. The samples were immediately snap frozen in liquid nitrogen and stored at $-80^{\circ} \mathrm{C}$. The incision site was stapled and treated topically with iodine spray. Staples were removed after 7 to $10 \mathrm{~d}$.

The adipose tissue samples were taken from the subcutaneous fat pad around the pin bones. Biopsies were taken before and after the GTT from contralateral sides of the tail head region. The biopsy site, a $5 \times$ 5 -cm area of skin on one side of the pin bone, was prepared by clipping, washing, and sterilizing with $70 \%$ alcohol and an iodine surgical scrub. The biopsy site was anesthetized by a 4 -mL subcutaneous injection of $2 \%$ lidocaine $\mathrm{HCl}$ (Esracain 2\%, $200 \mathrm{mg}$ per $10 \mathrm{~mL}$; Rafa Laboratories Ltd.). Aseptic techniques were used in making a $1.5-$ to 2.5 -cm scalpel incision through the skin and subcutaneous tissues. Four samples of approximately $40 \mathrm{mg}$ of fat tissue were captured by tweezers and cut off with scissors. The adipose tissue samples were washed with saline and then snap frozen in liquid nitrogen and stored at $-80^{\circ} \mathrm{C}$. Immediately 
after the biopsy, the wound was washed again with $70 \%$ alcohol, closed with staples, and covered with an aerosol bandage. Incision sites were inspected daily for $1 \mathrm{wk}$, kept clean, and treated with an aerosol bandage spray if necessary. Staples were removed after 7 to $10 \mathrm{~d}$.

\section{Processing of Adipose and Liver Tissues and Western Blot Analysis}

In total, liver and adipose samples from 6 cows were analyzed prepartum (2 cows were excluded from analysis as explained above), and samples from 8 cows were analyzed postpartum. For protein extraction, either 25 $\mathrm{mg}$ of liver tissue or approximately $40 \mathrm{mg}$ of adipose tissue were homogenized for 3 min with 2 metal beads ( $5 \mathrm{~mm}$ in diameter; Eldan Technologies, Petah Tikva, Israel) in $1 \mathrm{~mL}$ of prechilled lysis buffer containing protease and phosphatase inhibitors (Sigma-Aldrich, Rehovot, Israel), as described by Locher et al. (2011). Samples were incubated for $1 \mathrm{~h}$ at $4^{\circ} \mathrm{C}$ under continuous shaking, and then the homogenate was centrifuged at $20,000 \times g$ for $15 \mathrm{~min}$ at $4^{\circ} \mathrm{C}$ to remove lipids and other particulate materials. The liquid phase was collected and stored in $-80^{\circ} \mathrm{C}$ until electrophoresis. Protein concentration of the homogenate was measured according to the Bradford protein assay (Bio-Rad protein quantification kit; Bio-Rad Laboratories Inc., Hercules, CA). Thirty-five-microgram samples in Laemmli loading buffer (Laemmli, 1970) were resolved by SDS-PAGE under reducing conditions and were transferred into a nitrocellulose membrane for Western blotting with the following antibodies: $\beta$-subunit of insulin receptor (sc-711; Santa Cruz Biotechnology Inc., Santa Cruz, $\mathrm{CA}$ ), phosphorylated $\beta$-subunit of insulin receptor (sc25103R; Santa Cruz Biotechnology Inc.), general Akt (\#C67E7; Cell Signaling Technology Inc., Danvers, MA), phosphorylated $\mathrm{Akt}_{473}$ (Ser473, \#9271; Cell Sig- naling Technology Inc.), and actin (\#1844-1; Epitomics Inc., Burlingame, CA). Enhanced chemiluminescence reaction was used for protein detection. Data were processed and analyzed by densitometry using ImageJ software (National Institutes of Health, Bethesda, $\mathrm{MD})$. To ensure that quantitative data were obtained, chemiluminescence signals were measured with at least 5 consecutive exposure times to determine the linear range of signal intensity of each antibody. Specific band signals were normalized to the actin or total protein signal as an internal standard.

\section{Quantitative Real-Time PCR}

For RNA extraction, $25 \mathrm{mg}$ of liver tissue samples was homogenized with 2 metal beads in $400 \mu \mathrm{L}$ of lysis solution according to the PerfectPure RNA tissue kit (5 Prime Inc., Gaithersburg, MD). First-strand cDNA was generated by a cDNA reverse transcription kit (Applied Biosystems Inc., Foster City, CA). Quantitative detection of specific mRNA transcripts was carried out by real-time PCR using an ABI-PRISM 7300 instrument (Applied Biosystems Inc.) using SYBR green PCR mix (Invitrogen Corp., Carlsbad, CA) and the following primers (400 nM; Table 2): tyrosine3-monooxygenase/ tryptophan5-monooxygenase activation protein, zeta polypeptide (YWHAZ), PC, cytosolic PEPCK (PEPCKc), mitochondrial PEPCK 2 (PEPCKm), and glucose-6-phosphatase (G6Pase).

Three house-keeping genes were tested; actin, $18 \mathrm{~s}$, and $Y W H A Z$. Standard curves were produced for each primer, and the linearity of the response was examined; $Y W H A Z$ was chosen as the most reliable house-keeping gene in bovine liver, which is in accordance with the findings of (Lisowski et al., 2008). Therefore, data were normalized for the content of $Y W H A Z$ mRNA in liver samples.

Table 2. Polymerase chain reaction primer information

\begin{tabular}{|c|c|c|c|}
\hline Gene $^{1}$ & $\begin{array}{l}\text { GenBank } \\
\text { accession no. }\end{array}$ & Sequence $5^{\prime}>3^{\prime 2}$ & Reference \\
\hline$Y W H A Z$ & NW_001493253 & $\begin{array}{l}\text { F: GGAGGGTCGTCTCCAGTATTGA } \\
\text { R: CGAGCCATCTGCTGTTTTTTC }\end{array}$ & Lisowski et al. (2008) \\
\hline PEPCKC & AY145503 & $\begin{array}{l}\text { F: AACCTGGCCATGATGAACCCTACT } \\
\text { R: ACTCCTTGCCCTTCCAGGAAATGA }\end{array}$ & White et al. (2011) \\
\hline G6Pase & AY279358.1 & $\begin{array}{l}\text { F: TGATGGACCAAGAAAGATCCAGGG } \\
\text { R: TAGGGATTGACCTCACTGGCCCTCTT }\end{array}$ & White et al. (2011) \\
\hline
\end{tabular}

${ }^{1} Y W H A Z=$ tyrosine 3-monooxygenase/tryptophan 5-monooxygenase activation protein, zeta polypeptide; $P C=$ pyruvate carboxylase; $P E P C K c$ $=$ cytosolic phosphoenolpyruvate carboxykinase; $P E P C K m=$ mitochondrial phosphoenolpyruvate carboxykinase 2 ; G6Pase $=$ glucose-6-phosphatase.

${ }^{2} \mathrm{~F}=$ forward; $\mathrm{R}=$ reverse. 
The PCR products were subjected to DNA sequencing. Sequencing results ensured that the products were indeed encoding for PC, PEPCKc, PEPCKm, and G6Pase.

\section{Calculations and Statistical Analysis}

The patterns of glucose and insulin during the glucose challenge were analyzed by using the methods described by Opsomer et al. (1999). Glucose tolerance was estimated by calculating parameters that describe the clearance of the infused glucose. The fractional turnover rate $(\boldsymbol{k})$, the half-life $\left(\mathbf{T}_{\mathbf{1} / \mathbf{2}}\right.$; the time required for glucose concentration to fall by one half), and the area under the curve (AUC) at 60 min after infusion, beginning at $\mathrm{T}_{5}(5 \mathrm{~min}$ after infusion started), were calculated: $k$-value $(\% / \mathrm{min})=100 \times\left\{\left[\ln \left(\right.\right.\right.$ glucose $\left.\mathrm{T}_{15}\right)$ $-\ln \left(\right.$ glucose $\left.\left.\left.\mathrm{T}_{45}\right)\right] /\left(\mathrm{T}_{45}-\mathrm{T}_{15}\right)\right\} ; \mathrm{T}_{1 / 2}(\min )=100 \times$ $(0.693 / k)$.

The insulin response to the glucose infusion was determined by insulin peak, insulin increment (insulin peak level - basal insulin level) and AUC between $\mathrm{T}_{5}$ and $\mathrm{T}_{60}$. For AUC calculations, the data of glucose and insulin plasma concentrations was transformed to AUC against time ( $\mathrm{min}$ ) by the trapezoid method after deducting the basal concentrations of glucose or insulin from the measurements of each cow.

Glucose, NEFA, and insulin response to GTT between periods (prepartum, postpartum, and mid lactation), relative quantity of mRNA, BW, and BCS parameters were analyzed with the general linear models (GLM) procedure of SAS (version 9.2; SAS Institute Inc., Cary, NC). The model included effects of period and cow.

Continuous variables (milk and FCM production and daily plasma NEFA concentrations) were analyzed as repeated measurements using PROC MIXED SAS (version 9.2). Subgroup was analyzed as a fixed effect, whereas the cow was analyzed random effect in the statistical model.

The model used was $Y_{\mathrm{ijkl}}=\mu+\mathrm{G}_{\mathrm{i}}+\mathrm{C}(\mathrm{G})_{\mathrm{ij}}+\mathrm{DIM}_{\mathrm{ijk}}$ $+\operatorname{DIM}_{\mathrm{ijk}} \times \mathrm{DIM}_{\mathrm{ijk}}+\mathrm{E}_{\mathrm{ijk}}$, where $\mathrm{Y}_{\mathrm{ijkl}}=$ dependent variable, $\mu=$ overall mean, $\mathrm{G}_{\mathrm{i}}=$ subgroup i effect [high weight loss (HWL) or low weight loss $(\mathbf{L W L})], \mathrm{C}(\mathrm{G})$ ${ }_{\mathrm{ij}}=$ cow $\mathrm{j}$ nested in subgroup $\mathrm{i}, \mathrm{DIM}_{\mathrm{ijk}}=$ DIM as continuous variable, and $\mathrm{E}_{\mathrm{ijkl}}=$ random residual. The autoregressive order one (AR 1) was used as a covariance structure in the model. The differences of least squares means between treatments of the MIXED Procedure were used for comparative effects.

Protein levels were analyzed as a 3 factors experiment using PROC GLM SAS (version 9.2). Period $\times$ cow and GTT $\times$ cow nested in subgroup were analyzed as random effects in the model.
The structural model of this analysis was $\mathrm{Y}_{\mathrm{ijklmnopqr}}=$ $\mu+\mathrm{G}_{\mathrm{i}}+\mathrm{C}(\mathrm{G})_{\mathrm{ij}}+\mathrm{P}_{\mathrm{ijk}}+\mathrm{I}_{\mathrm{ijkl}}+(\mathrm{G} \times \mathrm{P})_{\mathrm{ijklm}}+(\mathrm{G} \times \mathrm{I})$ $\mathrm{ijklmn}+\mathrm{P} \times \mathrm{C}(\mathrm{G})_{\mathrm{ijk} k m n o}+\mathrm{I} \times \mathrm{C}(\mathrm{G})_{\mathrm{ijk} k \mathrm{mnop}}+(\mathrm{G} \times \mathrm{P} \times$ $\mathrm{I})_{\mathrm{ijk} k m n o p q}+\mathrm{E}_{\mathrm{ijk} k m n o p q r}$, where $\mathrm{Y}_{\mathrm{ijklmnopqr}}=$ dependent variable, $\mu=$ overall mean, $\mathrm{G}_{\mathrm{i}}=$ subgroup i effect (HWL or $\mathrm{LWL}), \mathrm{C}(\mathrm{G})_{\mathrm{ij}}=$ cow $\mathrm{j}$ nested in subgroup $\mathrm{ij}, \mathrm{P}_{\mathrm{ijk}}$ $=$ period (pre- or postpartum), $\mathrm{I}_{\mathrm{ijk}}=\mathrm{GTT}$ (before or after $),(\mathrm{G} \times \mathrm{P})_{\mathrm{ijklm}}=\operatorname{subgroup~} \mathrm{i} \times \operatorname{period} \mathrm{k},(\mathrm{G} \times \mathrm{I})$ $\mathrm{ijklmn}=$ subgroup $\mathrm{i} \times \mathrm{GTT} \mathrm{l}, \mathrm{P} \times \mathrm{C}(\mathrm{G})_{\mathrm{ijk} k \mathrm{mno}}=$ period $\mathrm{k} \times$ cow $\mathrm{j}$ nested in subgroup $\mathrm{i}, \mathrm{I} \times \mathrm{C}(\mathrm{G})_{\mathrm{ijklmnop}}=\mathrm{GTT}$ $1 \times$ cow $\mathrm{j}$ nested in subgroup i, $(\mathrm{G} \times \mathrm{P} \times \mathrm{I})_{\mathrm{ijklmnopq}}$ $=$ subgroup $\mathrm{i} \times$ period $\mathrm{k} \times \mathrm{GTT} \mathrm{l}$, and $\mathrm{E}_{\mathrm{ijk} k \mathrm{lmnopqr}}=$ random residual; PROC REG of SAS (version 9.2) was used for correlation analysis; $P<0.05$ was accepted as statistically significant, and tendencies were reported at $0.05<P<0.10$.

\section{RESULTS}

\section{Cow Characterization}

Eight cows were analyzed throughout the study. Their average BW at $4 \mathrm{~d}$ postpartum was $663 \pm 46 \mathrm{~kg}$ and their average milk production and $4 \% \mathrm{FCM}$ during the first $100 \mathrm{~d}$ in lactation were $50.8 \pm 10.8$ and $48.9 \pm$ $10.8 \mathrm{~kg} / \mathrm{d}$, respectively.

\section{Basal Plasma Insulin Concentrations and Response to GTT}

Basal insulin concentrations were higher $17 \mathrm{~d}$ prepartum than at 3 to $5 \mathrm{~d}$ postpartum (Table $3 ; P<0.02$ ). Insulin response to GTT, as expressed by peak insulin concentrations, insulin increment, and AUC were approximately 4 -fold higher prepartum than postpartum (Table 3 and Figure 1; $P<0.001$ ). The clearance of glucose from blood after GTT, as expressed by glucose turnover rate and $\mathrm{T}_{1 / 2}$, was not different pre- and postpartum. Basal plasma glucose concentrations in mid lactation were similar to prepartum values and higher than in early lactation $(P<0.02$; Table 3$)$. Still, basal plasma insulin concentrations $(P<0.0001)$, insulin response to GTT $(P<0.0007)$, insulin increment $(P<$ $0.001)$, and insulin AUC $(P<0.0009)$ in mid lactation were similar to early postpartum values and lower than prepartum concentrations (Table 3).

The NEFA concentrations in plasma were also determined in response to GTT (Figure 2). The basal NEFA concentrations before glucose infusion were 5.1-fold higher postpartum than prepartum $(1,618.6$ and 315.5 $\mu \mathrm{Eq} / \mathrm{L}$, respectively; $\mathrm{SEM}=80.5 ; P<0.0001)$. Both pre- and postpartum, NEFA concentrations decreased following glucose infusion, reached a steady state around 45 min after infusion, and were 6.8 fold higher 
Table 3. Kinetics of response to glucose tolerance tests (GTT) in prepartum, postpartum, and mid-lactation cows

\begin{tabular}{|c|c|c|c|c|c|}
\hline Period & Prepartum & Postpartum & Mid lactation & SEM & $P$-value \\
\hline Glucose turnover rate $(k), \% / \min$ & 1.5 & 1.7 & 1.6 & 0.2 & NS \\
\hline Glucose $\mathrm{T}_{1 / 2},{ }^{1} \min$ & 45.9 & 42.3 & 47.6 & 5.1 & NS \\
\hline Basal insulin, $\mathrm{pg} / \mathrm{mL}$ & $280.0^{\mathrm{a}}$ & $68.3^{\mathrm{b}}$ & $62.6^{\mathrm{b}}$ & 19.1 & $<0.0001$ \\
\hline Peak insulin, pg/mL & $4,286.1$ & $1,067.9^{\mathrm{b}}$ & $735.9^{\mathrm{b}}$ & 529.3 & $<0.0007$ \\
\hline Insulin increment, $\mathrm{pg} / \mathrm{mL}$ & $4,000.1^{\mathrm{a}}$ & $999.6^{\mathrm{b}}$ & $673.2^{\mathrm{b}}$ & 536.4 & $<0.001$ \\
\hline
\end{tabular}

${ }^{\mathrm{a}, \mathrm{b}}$ Means within a row with different superscripts differ $(P<0.05)$.

${ }^{1} \mathrm{~T}_{1 / 2}=$ half life.

${ }^{2} \mathrm{AUC}=$ area under the curve.

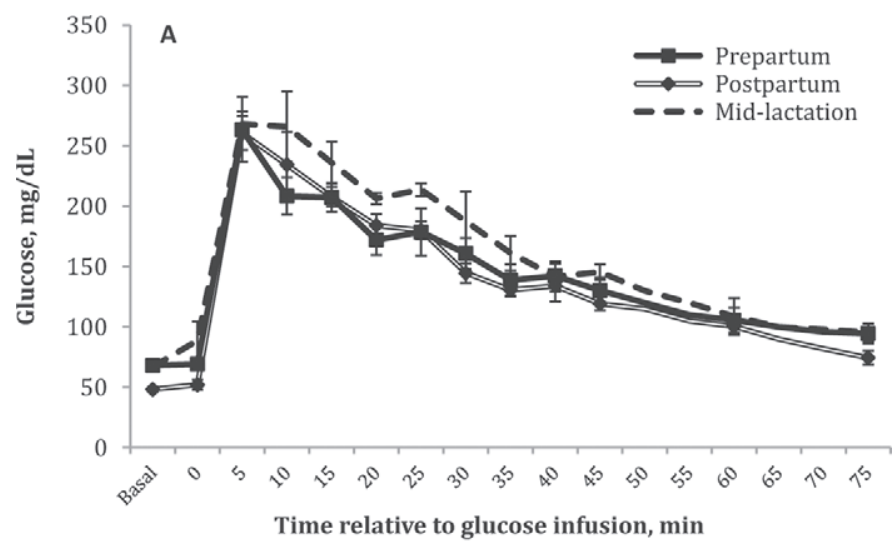

postpartum than prepartum (758.1 and $111.2 \mu \mathrm{Eq} / \mathrm{L}$, respectively; $\mathrm{SEM}=133.1 ; P<0.006)$.

\section{mRNA Expression of Gluconeogenic Enzymes in the Liver}

To confirm that the cows were at 2 different metabolic states at the time of sampling pre- and postpartum and to examine the correlation with insulin concentrations, we examined the mRNA expression of key gluconeogenic enzymes in the liver. As expected, the relative quantity (RQ) of PC mRNA in liver samples was 7.5-fold higher at $4 \mathrm{~d}$ postpartum compared with $17 \mathrm{~d}$ prepartum $(P<0.0001$; Figure 3$)$, whereas the RQ of PEPCKc and PEPCKm mRNA increased by $3.1(P<$ $0.003)$ and $1.5(P<0.04)$ fold postpartum compared with prepartum, respectively (Figure 3). However, the G6Pase mRNA in liver samples did not differ between pre- and postpartum. For all the examined enzymes, the relative quantity of mRNA was not affected by GTT. As expected, the RQ of PC mRNA pre- and postpartum was negatively correlated with the basal plasma insulin concentrations $(\mathrm{r}=-0.85 ; P<0.0001)$. The RQ of PEPCKc mRNA pre- and postpartum tended to be negatively correlated with basal plasma insulin concentrations $(\mathrm{r}=-0.38 ; P<0.07)$.

\section{Protein Levels of IR and Phosphorylation of IR in the Liver}

The liver is a major insulin responsive tissue; therefore, 2 critical elements along the insulin signaling were analyzed in liver biopsies before and after GTT: the IR and its downstream effector protein kinase B (also known as Akt). The specificity of the antibody to the $\beta$-subunit of bovine IR was confirmed by immunoprecipitation; it was found that the phosphorylated IR antibody binds specifically to the $\beta$-subunit of IR, at a molecular weight of approximately $95 \mathrm{kDa}$ (data not shown). The basal amount of IR in liver (before GTT) 

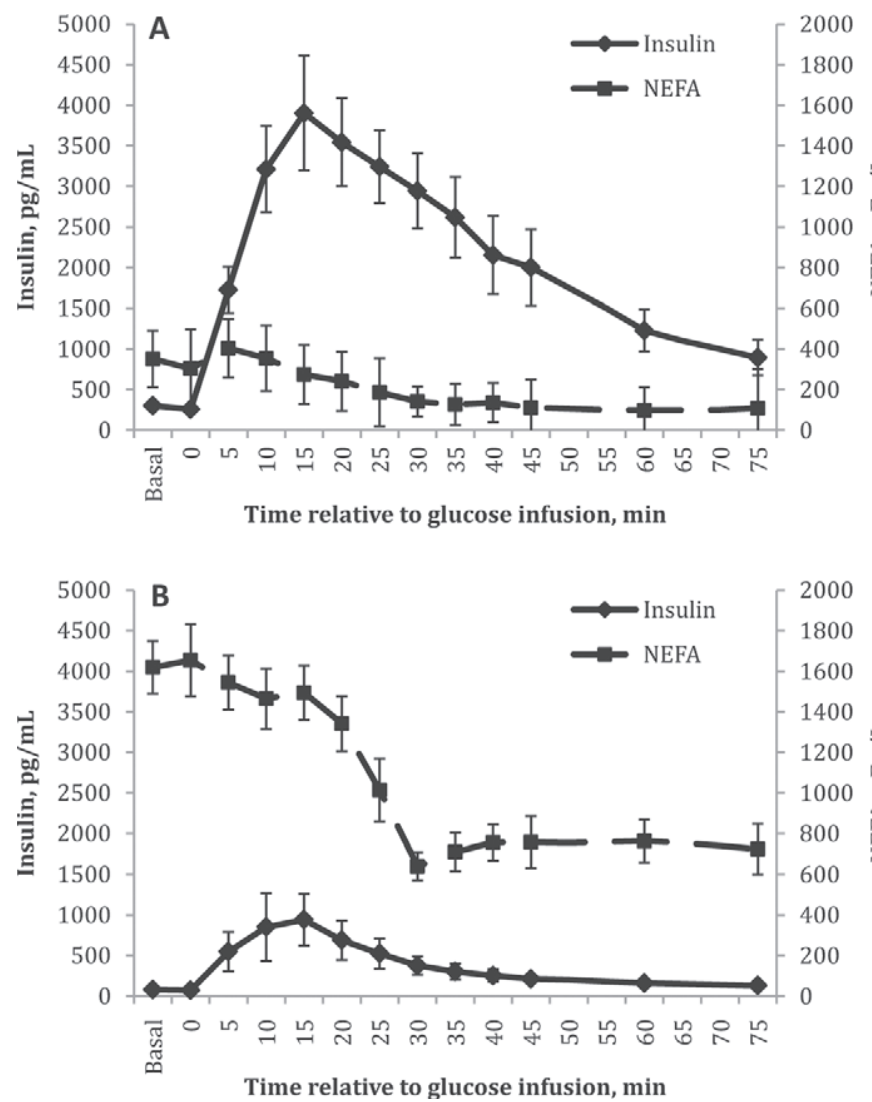

Figure 2. Plasma insulin and NEFA concentrations in response to glucose tolerance tests (GTT) in cows in late pregnancy (A) and early lactation (B). Plasma insulin and NEFA concentrations were determined at the indicated times in response to GTT performed in 260-d-pregnant, nonlactating cows (prepartum; A) and at $4 \mathrm{~d}$ after calving (postpartum; B). Data are LSM \pm SEM.

was higher postpartum than prepartum $(P<0.003$; data not shown).

Tyrosine phosphorylation of IR, as expressed by the ratio of phosphorylated IR to total IR (Figure 4a), was increased in response to GTT by 2.4 fold prepartum $(P<0.0001)$ and by 1.4 fold postpartum $(P<0.03)$. Moreover, the level of IR phosphorylation did not differ at the basal state (before GTT) pre- and postpartum, whereas the magnitude of Tyr phosphorylation in response to GTT was higher prepartum compared with postpartum $(P<0.0002)$. A significant effect of period (pre- and postpartum; $P<0.0007)$ and of GTT $(P<$ 0.0002) was observed on Tyr phosphorylation of IR, and the interaction period $\times$ GTT was also significant $(P<0.003)$. A representative blot of 2 out of 8 cows is shown in Figure 4b. Across periods, a positive correlation was observed between basal plasma insulin values and the ratio of phosphorylated IR to total IR after GTT ( $\mathrm{r}=0.75 ; P<0.008$; Figure 5a). Also, the ratio of phosphorylated IR to total IR correlated with the peak

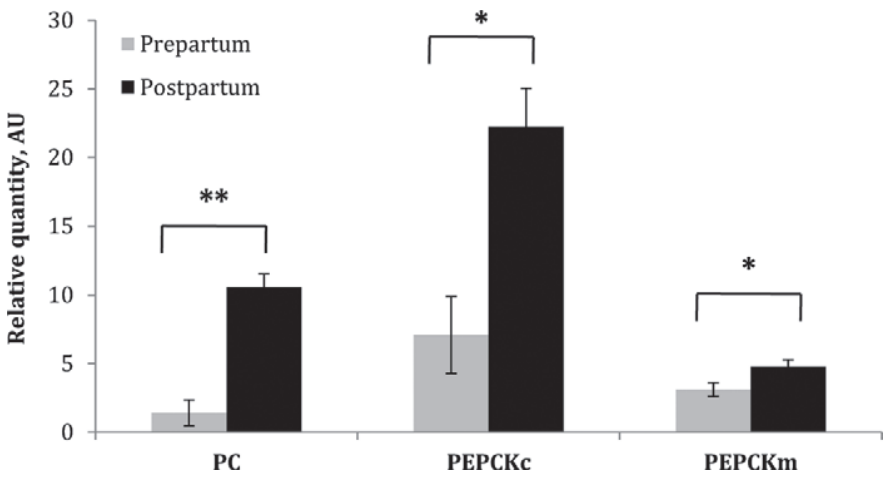

Figure 3. Messenger RNA levels of gluconeogenic key enzymes in the liver from cows in late pregnancy and early lactation. Total RNA was extracted from liver biopsies obtained from 260-d-pregnant, nonlactating cows (prepartum) and cows at $4 \mathrm{~d}$ after calving (postpartum) and quantitative real-time PCR was conducted. Relative quantities of mRNA for the gluconeogenic enzymes pyruvate carboxylase (PC), cytosolic phosphoenolpyruvate carboxykinase (PEPCKc), and mitochondrial PEPCK (PEPCKm) were determined; the mRNA levels were normalized to tyrosine3-monooxygenase/tryptophan5-monooxygenase activation protein, zeta polypeptide (YWHAZ). ${ }^{*} P<0.05$; ${ }^{* *} P<$ 0.0001. The error bars represent SEM of the relative quantity of the corresponding enzyme.

insulin concentration in response to GTT $(\mathrm{r}=0.72 ; P$ $<0.01$; Figure 5b).

\section{Phosphorylation of Akt $_{473}$ in the Liver}

Protein kinase B (Akt) is a downstream element in the PI3K pathway mediated by insulin. Activated Akt is phosphorylated on 2 sites: Thr $308\left(\mathrm{Akt}_{308}\right)$ and Ser $473\left(\mathrm{Akt}_{473}\right)$. Total Akt proteins in liver were not different pre- and postpartum, and were not affected by GTT (data not shown). Yet, the magnitude of $\mathrm{Akt}_{473}$ phosphorylation in response to GTT was lower postpartum compared with prepartum $(P<0.03$; Figure 6a and $6 \mathrm{~b}$ ). However, due to the higher basal level of phosphorylated Akt prepartum, the ratio of phosphorylated Akt/total Akt in response to GTT was increased by 3.7 and 5.6 fold prepartum or postpartum $(P<0.008)$, respectively. The effect of period (pre- and postpartum) on $\mathrm{Akt}_{473}$ phosphorylation tended to be significant $(P$ $<0.07)$, and the effect of GTT was significant $(P<$ 0.001). Across periods, the correlation between peak plasma insulin and phosphorylated Akt/total Akt in response to GTT tended to be significant $(\mathrm{r}=0.46 ; P$ $<0.1)$.

\section{Phosphorylation of Akt $_{473}$ in the Adipose Tissue}

The amount of total IR in adipose tissue was not different pre- and postpartum and was not affected by GTT (data not shown). We could not detect phosphorylated IR in the adipose tissue; therefore, insulin 
A

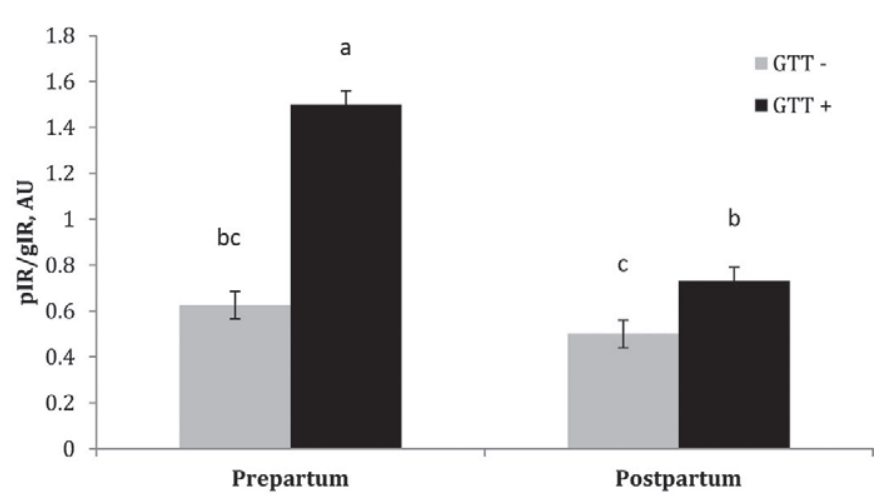

B

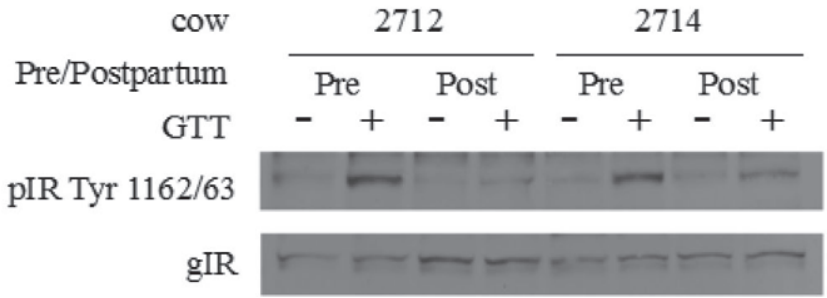

Figure 4. Phosphorylation of insulin receptors (IR) in liver in response to glucose tolerance tests (GTT) pre- and postpartum. Total protein extractions $(30 \mu \mathrm{g})$ from liver biopsies from 260-d-pregnant, nonlactating cows (prepartum) and cows at $4 \mathrm{~d}$ after calving (postpartum) before and $30 \mathrm{~min}$ after glucose tolerance tests were resolved by SDS-PAGE. Proteins were immunoblotted with phosphorylated (pIR) and general IR (gIR) antibodies, as indicated. Densitometry analysis of 8 cows (mean \pm SEM) is presented as bar graphs (A), and representative blots of 2 cows are displayed (B). Means with different letters $(\mathrm{a}-\mathrm{c})$ differ $(P<0.05)$.

signaling was examined by the phosphorylation of $\mathrm{Akt}_{473}$ in response to GTT. The amount of total Akt in adipose tissue was not different pre- and postpartum and was not affected by GTT (data not shown). However, Akt phosphorylation (Ser 473) in response to GTT was increased by 2.2 fold prepartum, with no significant increase postpartum $(P<0.2$; Figure 7$)$, and the interaction period $\times$ GTT tended to be significant $(P<0.07)$. Across periods, a positive correlation was observed between basal and peak plasma insulin values and the ratio of phosphorylated Akt to total Akt after GTT $(\mathrm{r}=0.65$ and $\mathrm{r}=0.59$, respectively; $P<0.04$; Figure 8). Yet, examining the specific response of each cow revealed that even though the insulin response to GTT was similar in all 8 cows, 4 out of 8 cows did increase $\mathrm{Akt}_{473}$ phosphorylation in adipose tissue in response to GTT both pre- and postpartum $(P<0.01)$, whereas the other 4 cows did not (Figure 9a). Of note, Akt phosphorylation in the liver in response to GTT was similar in all cows (Figure 9b).

When characterizing these subgroups, it was found that they were distinguished by several aspects; al-
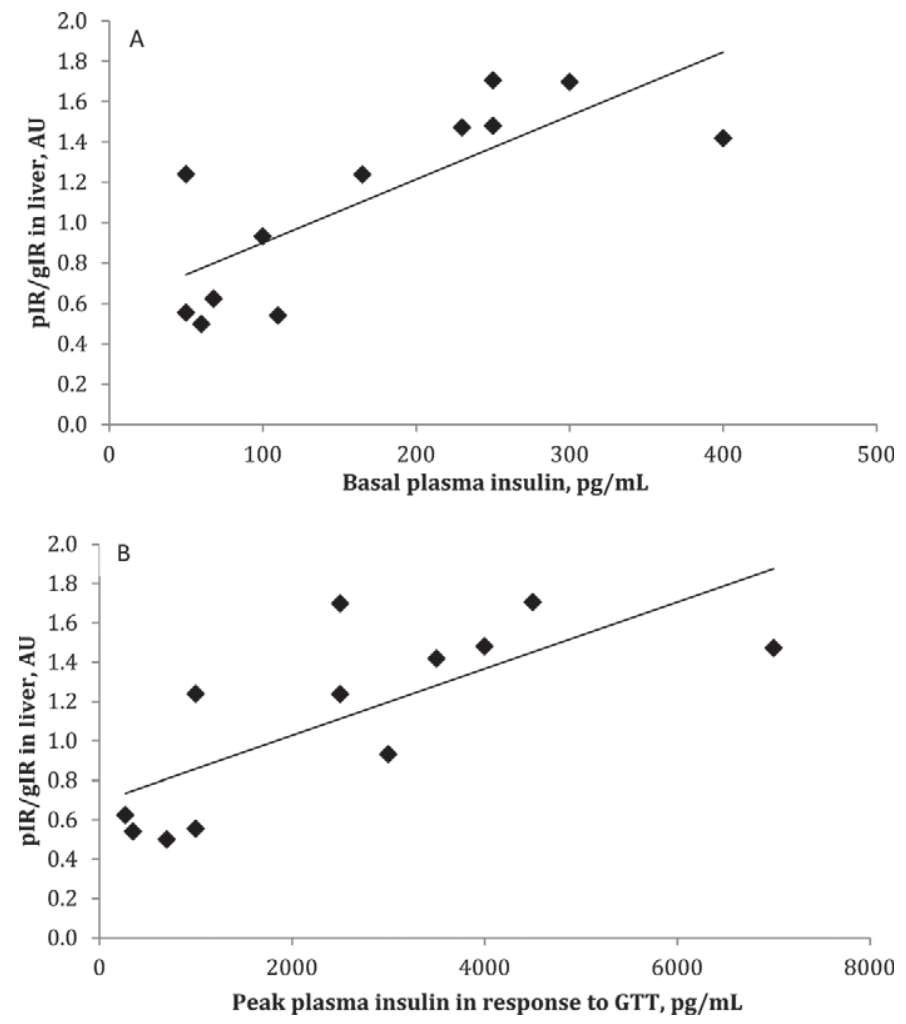

Figure 5. Positive correlations between basal plasma insulin and peak insulin in response to glucose tolerance tests (GTT) and phosphorylation of insulin receptors (IR) in the liver. Densitometry analysis of phosphorylated IR (pIR; Tyr 1162/63) to total IR (general IR, gIR) in liver biopsies from 8 cows obtained 30 min after GTT was plotted against basal plasma insulin $(\mathrm{r}=0.75, P<0.008$; $\mathrm{A})$ and peak insulin $(\mathrm{r}=0.72, P<0.01 ; \mathrm{B})$ in response to glucose GTT performed in 260-d-pregnant, nonlactating cows (prepartum) and cows at $4 \mathrm{~d}$ after calving (postpartum).

though the BW of the cows did not differ at $17 \mathrm{~d}$ prepartum, one subgroup of cows lost significantly more BW between the first week and wk 5 postpartum $(54.5$ $\mathrm{kg}$ vs. $11.8 \mathrm{~kg}$ in the other subgroup; $\mathrm{SEM}=7.4 ; P<$ $0.006)$, and also greater loss of weight, as expressed by percentage of $\mathrm{BW}$, was observed in these cows (8 vs. $2 \%$; SEM $=0.008 ; P<0.003)$. Therefore, we defined the subgroups as follows: (1) HWL $(\mathrm{n}=4)$ : high BW loss and adipose tissue unresponsive to insulin, and (2) LWL $(\mathrm{n}=4)$ : low BW loss and adipose tissue responsive to insulin. Body condition score is an indicator to the amount of body fat reserves; we observed that although all cows began the experiment (at $261 \pm 5 \mathrm{~d}$ of pregnancy) with similar BCS (3.4 \pm 0.1 units), the LWL cows lost less BCS units between $17 \mathrm{~d}$ prepartum and 3 to $5 \mathrm{~d}$ postpartum than HWL cows $(-0.15$ and -0.58 units, respectively; $\mathrm{SEM}=0.12 ; P<0.04)$, so that the BCS at 3 to $5 \mathrm{~d}$ postpartum tended to be lower in HWL cows compared with LWL (2.70 vs. 3.35 units, respectively; SEM $=0.26 ; P<0.13)$. Also, the 
A

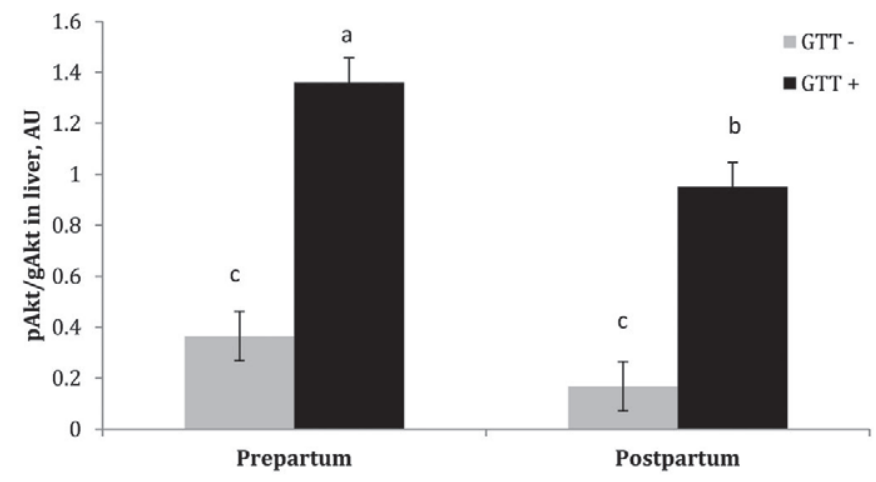

B

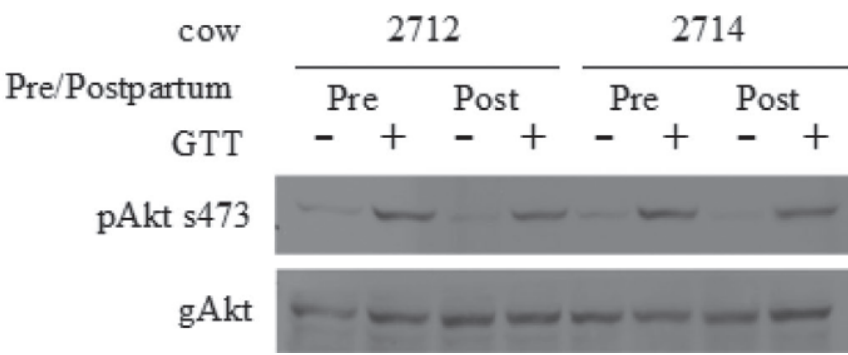

Figure 6. Phosphorylation of protein kinase B (Akt) in the liver in response to glucose tolerance tests (GTT) pre- and postpartum. Total protein extractions $(30 \mu \mathrm{g})$ from liver biopsies from 260-d-pregnant, nonlactating cows (prepartum), and cows at $4 \mathrm{~d}$ after calving (postpartum) before and 30 min after GTT were resolved by SDS-PAGE. Proteins were immunoblotted with phosphorylated (pAkt; Ser 473) and general Akt (gAkt) antibodies, as indicated. Densitometry analysis of 6 cows (mean \pm SEM) is presented as bar graphs (A), and representative blots of 2 cows are displayed (B). Means with different letters $(\mathrm{a}-\mathrm{c})$ differ $(P<0.05)$

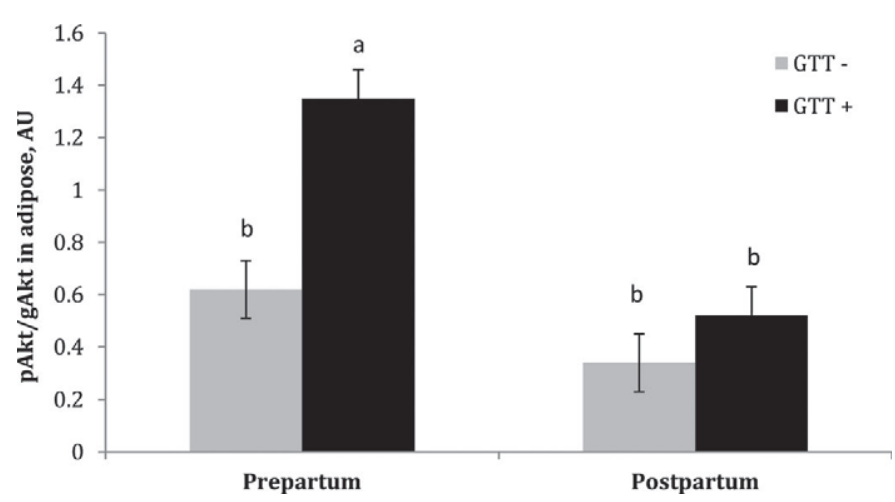

Figure 7. Phosphorylation of protein kinase B (Akt) in adipose tissue in response to glucose tolerance tests (GTT) pre- and postpartum. Total protein extractions $(30 \mu \mathrm{g})$ from adipose biopsies from $260-\mathrm{d}$ pregnant, nonlactating cows (prepartum) and cows at $4 \mathrm{~d}$ after calving (postpartum) before and $30 \mathrm{~min}$ after GTT were resolved by SDSPAGE. Proteins were immunoblotted with phosphorylated (pAkt; Ser 473) and general Akt (gAkt) antibodies, as indicated. Densitometry analysis of 8 cows (mean \pm SEM) is presented as bar graphs. Means with different letters $(\mathrm{a}$ and $\mathrm{b})$ differ $(P<0.05)$.
BCS of HWL cows at $14 \mathrm{~d}$ postpartum was lower than in LWL cows (2.20 and 3.23 units, respectively; SEM = $0.20 ; P<0.02$ ), and tended to be lower in HWL cows at $28 \mathrm{~d}$ postpartum compared with LWL (2.06 and 2.90 units, respectively; SEM $=0.25 ; P<0.07)$. The high loss of BW in HWL cows was further supported by numerically (33\%) increased NEFA concentrations in plasma during the period of 2 wk prepartum to 2 wk postpartum compared with LWL cows (471.8 vs. 356.3 $\mu \mathrm{Eq} / \mathrm{L}$, respectively; $\mathrm{SEM}=77 ; P<0.3)$. Differences between subgroups were also observed in production parameters; the milk and FCM yields during the first $100 \mathrm{~d}$ in lactation were lower in HWL than LWL cows [46.8 vs. $55.4 \mathrm{~kg} / \mathrm{d}, \mathrm{SEM}=1.8 ; P<0.001$ (Figure $10)$; and 45.0 vs. $53.0 \mathrm{~kg} / \mathrm{d}, \mathrm{SEM}=2.9 ; P<0.05$, respectively]. Also, the 305-d 4\% FCM production of the previous lactation, which is an indicator of production potential, was lower in HWL than LWL cows (36.4 and $39.7 \mathrm{~kg} / \mathrm{d}$, respectively; $\mathrm{SEM}=0.7 ; P<0.03)$.
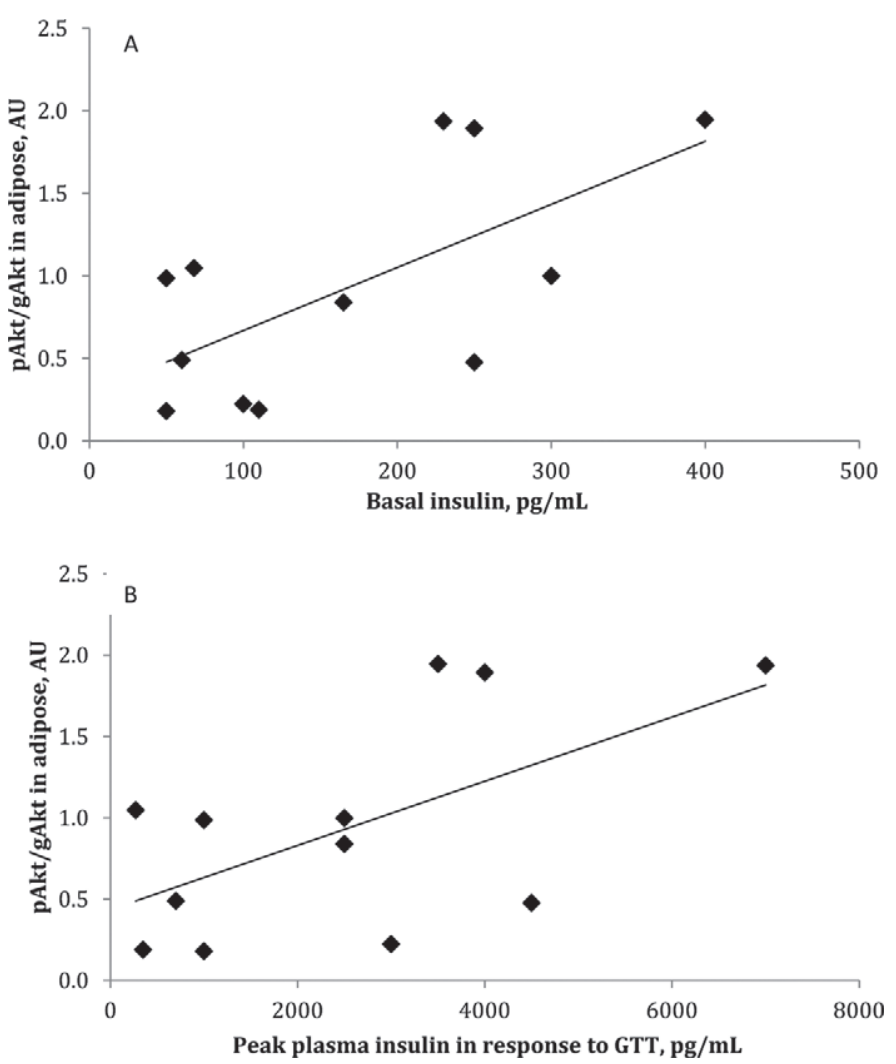

Figure 8. Positive correlations between basal plasma insulin (A) and peak insulin (B) in response to glucose tolerance tests (GTT) and phosphorylation of protein kinase B (Akt) in adipose tissue. Densitometry analysis of phosphorylated Akt (pAkt; Ser 473) to total Akt (general Akt, gAkt) in adipose tissue biopsies obtained 30 min after GTT was plotted against basal plasma insulin $(\mathrm{r}=0.65, P<$ $0.04 ; \mathrm{A})$ and peak insulin $(\mathrm{r}=0.59, P<0.04 ; \mathrm{B})$ in response to GTT performed in 260-d-pregnant, nonlactating cows (prepartum) and cows at $4 \mathrm{~d}$ after calving (postpartum). 

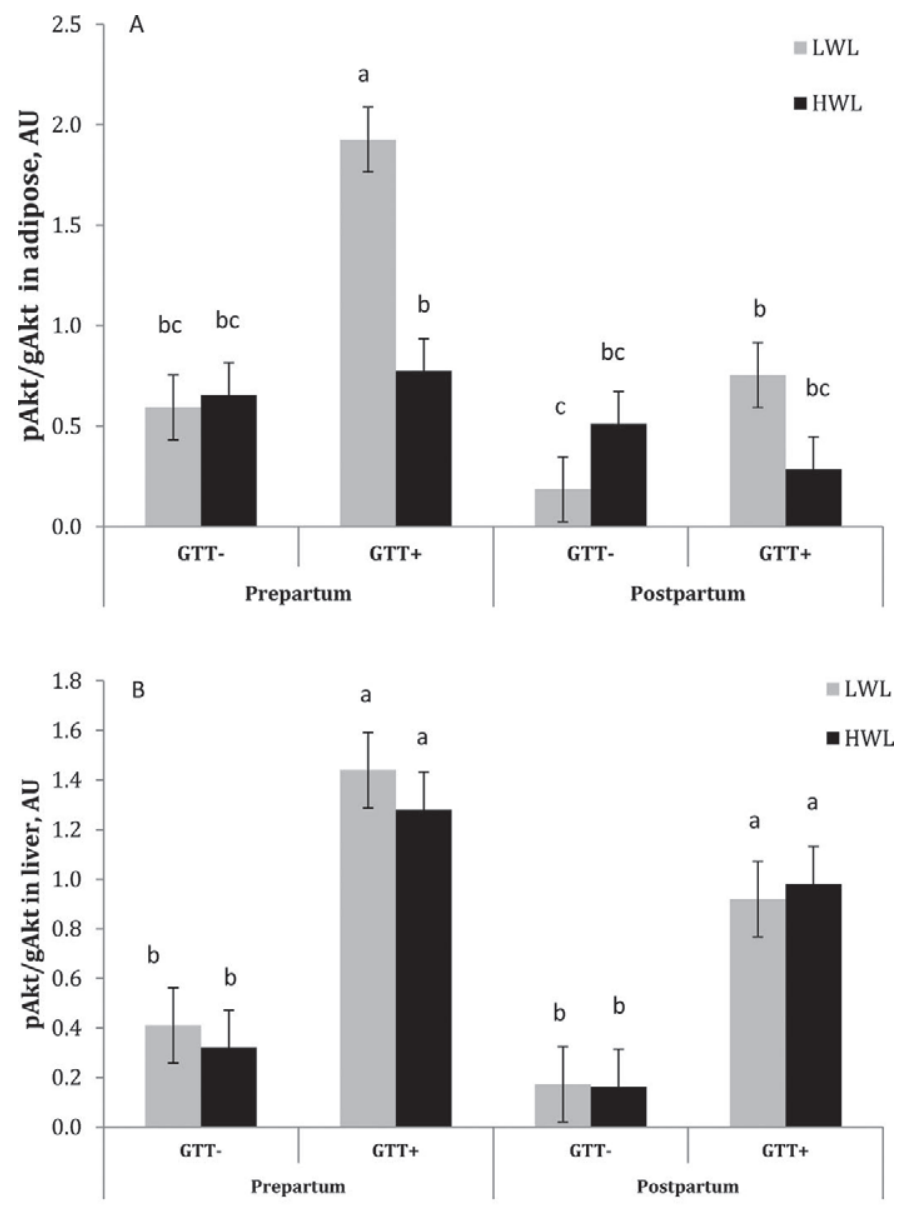

C

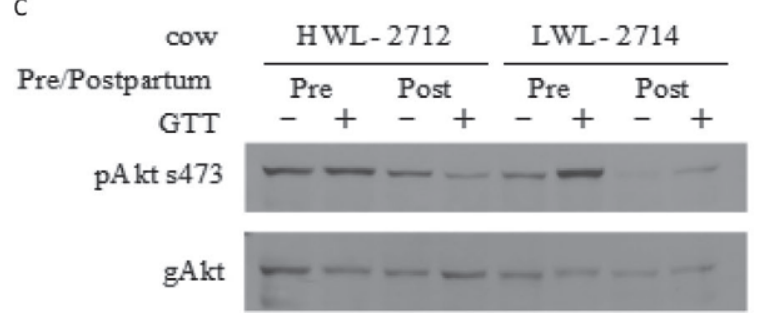

Figure 9. Phosphorylation of protein kinase B (Akt) in adipose tissue (A) and liver (B) in response to glucose tolerance tests (GTT) preand postpartum in low-weight-loss (LWL) cows and high-weight-loss (HWL) cows and representative blots (C). Total protein extractions $(30 \mu \mathrm{g})$ from liver and adipose biopsies from 260-d-pregnant, nonlactating cows (prepartum) and cows at $4 \mathrm{~d}$ after calving (postpartum) before and 25 to $30 \mathrm{~min}$ after GTT were resolved by SDS-PAGE. Proteins were immunoblotted with phosphorylated (pAkt; Ser 473) and general Akt (gAkt) antibodies, as indicated. Densitometry analysis of $4 \mathrm{LWL}$ cows and $4 \mathrm{HWL}$ cows (mean \pm SEM) is presented as bar graphs. Representative blots of adipose tissue extracts from 2 cows are displayed $(\mathrm{C})$. Means with different letters $(\mathrm{a}-\mathrm{c})$ differ $(P<0.05)$.

\section{DISCUSSION}

In a state of insulin resistance, the sensitivity of target cells to respond to ordinary levels of insulin is reduced (Boura-Halfon and Zick, 2009). Thus, normal concen- trations of insulin produce a less-than-normal biologic response (Kahn, 1978). Whole-body insulin sensitivity was examined in the current study by calculating the kinetics of glucose and insulin response to GTT. Although the insulin response was significantly higher prepartum compared with early and mid lactation, the glucose clearance was similar at all times, indicating normal response to insulin stimulation. However, if we consider glucose clearance as a characteristic biological response to insulin, late-pregnant cows needed much more insulin for the same biologic response, which seemingly fits a classic state of insulin resistance (Zick, 2001; Samuel and Shulman, 2012). In this case, we would expect that the insulin signaling in the liver and in adipose tissue, which are major insulin-responsive tissues (muscle was not sampled in this study), would be similar or reduced in late-pregnant cows compared with early lactation, suggesting the expected reduced response to insulin of target tissues in a state of insulin resistance. However, the results of our study were opposite to this; the in vivo phosphorylation in response to GTT of IR and Akt, both in liver and in adipose tissue, were significantly higher prepartum than postpartum. These seemingly paradoxical results were nevertheless in correlation with the insulin levels, as pregnant cows had high plasma insulin concentrations in response to GTT, whereas at $4 \mathrm{~d}$ postpartum, the insulin response to GTT was significantly reduced. Accordingly, across periods, strong positive correlations were found between basal and peak plasma insulin concentrations and the degree of IR phosphorylation in liver and Akt phosphorylation in adipose tissue, in response to GTT. These findings imply an in vivo dose response phenomenon, where low plasma insulin results in weaker signaling and high plasma insulin causes elevated IR signaling in the liver, without altering glucose clear-

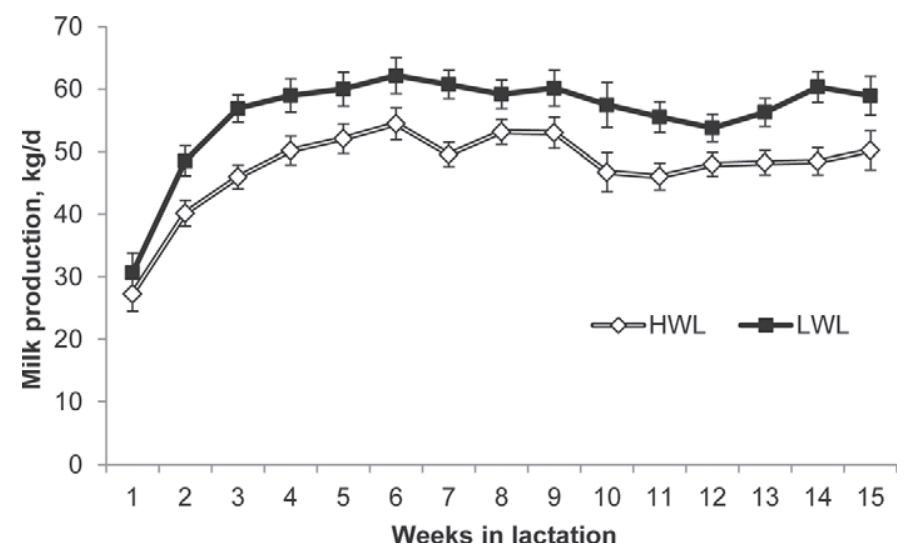

Figure 10. Average milk production during the first $100 \mathrm{~d}$ in lactation of low-weight-loss (LWL) and high-weight-loss (HWL) cows. The error bars represent the SEM of the milk yields. 
ance. Thus, the relatively low phosphorylation of IR and Akt that was observed postpartum was sufficiently high to induce normal clearance of glucose from the blood. This could be accounted for by the fact that different biological responses (e.g., glucose clearance, inhibition of gluconeogenesis, and lipogenesis) have different insulin sensitivities, which reflects the necessity for different receptor occupancy (Kahn, 1978). For example, in the case of insulin stimulation of glucose transport in adipose tissue, a maximal effect is achieved already at 2 to $10 \%$ receptor occupancy, a phenomenon denoted as "spare receptors" (Kahn, 1978). Therefore, the large number of IR per cell in insulin-responsive tissues is capable of inducing normal glucose clearance even with a low occupancy of insulin receptors. Because more insulin was secreted in response to a glucose load prepartum, a higher degree of phosphorylation of hepatic IR and Akt was observed in these animals.

This conclusion is further supported by the levels of expression of hepatic gluconeogenic enzymes. Insulin is the most important hormone that inhibits hepatic gluconeogenesis, and it acts predominantly by suppressing the expression of genes for the key gluconeogenic enzymes (Barthel and Schmoll, 2003). In accordance with the reduced insulin concentrations postpartum, we observed a 1.5- to 7.5-fold increase in the relative expression of key gluconeogenic enzymes (PC, PEPCKc, and PEPCKm) in the liver of postpartum cows compared with late pregnancy. Moreover, a negative correlation was observed between peripartum basal plasma insulin concentrations and the relative expression of $\mathrm{PC}(\mathrm{r}=$ $-0.85, P<0.0001)$. These findings are in agreement with others (Graber et al., 2010; White et al., 2011), as the rate of hepatic gluconeogenesis must abruptly double during the peripartum period to meet the high glucose demand of the mammary gland (Bell and Bauman, 1997).

Similar to our results in dairy cows, late-pregnant rats (Sevillano et al., 2007) and women (Ryan et al., 1985) exhibit high basal plasma insulin concentrations compared with nonpregnant controls. However, no phosphorylation of Akt in adipose tissue after insulin stimulation was detected in pregnant rats compared with virgin rats (Sevillano et al., 2007), implying unresponsiveness of adipose tissue to insulin stimulation in pregnant but not in virgin rats. This is a classic characteristic of insulin resistance, as high plasma insulin concentrations were coupled with a lack of response in adipose tissues. In contrast, in our study we found a strong positive correlation between plasma insulin concentrations and the phosphorylation of Akt in adipose tissues after GTT pre- and postpartum. This infers that the modern high-yielding dairy cow does not follow the classic model of adipose tissue-specific insulin resistance in late pregnancy that is evident in rats (Sevillano et al., 2007) and in humans (Ryan et al., 1985), perhaps due to metabolic adjustments to high milk production in this species. Furthermore, the positive correlation between insulin concentrations in plasma and phosphorylation of Akt in liver and adipose tissues supports our hypothesis that the natural decrease in insulin concentration peripartum, as a part of homeorhetic regulation, enables increased gluconeogenesis and lipolysis, which are essential in this period.

In the present study, the amount of total IR in liver at the basal state (before GTT) was higher postpartum compared with prepartum, which is in accordance with Gross et al. (2011), who observed increased mRNA abundance of hepatic IR during early lactation. It appears that the low plasma insulin level in early lactation causes an upregulation of the IR, perhaps to maintain the insulin function in the liver while maximizing nutrient supply to the mammary gland. On the other hand, the amount of total IR in adipose tissue samples (before and after GTT) was similar pre- and postpartum, which is in agreement with Wilson et al. (1996).

It is known that the mammary gland, placenta, and the gravid uterus are glucose-demanding organs (Bell and Bauman, 1997), and we cannot exclude their involvement in glucose clearance. Bell (1995) calculated that in $250 \mathrm{~d}$ pregnant dairy cows, $45 \%$ of maternal glucose supply (666 out of $1,476 \mathrm{~g} / \mathrm{d}$ ) is directed to the gravid uterus, compared with $85 \%$ of maternal glucose supply at $4 \mathrm{~d}$ in lactation $(1,775$ out of 2,089 $\mathrm{g} / \mathrm{d}$ ), in cows producing $29.6 \mathrm{~kg}$ of milk/d. In fact, the glucose demand at $250 \mathrm{~d}$ of pregnancy was equivalent to production of only $4.9 \mathrm{~kg}$ of milk/d (Bell, 1995). As the glucose demand of the uterus in late pregnancy is 3 -fold lower than that of the mammary gland in early lactation, we may assume that the mammary gland would take up much more glucose after GTT postpartum compared with the uterus of the prepartum cows. However, we observed the exact same kinetics of glucose clearance both pre- and postpartum, with no differences either in peak glucose values or in the slope of glucose clearance between the pre- and postpartum GTT. This can be explained by the hyperphysiological amounts of glucose during GTT ( $200 \mathrm{~g} / 3 \mathrm{~min})$, which may be beyond the glucose uptake rate of the uterus and the mammary gland; therefore, we assume that the insulin-responsive tissues (liver, adipose, and muscle) were the main tissues that responded to this stimulation to inhibit glucose production in the liver or to take up glucose to muscle and fat tissues. In accordance with this assumption, at least in regard to the prepartum animals, in a study conducted in pregnant women using the euglycemic clamp technique, it was found that glucose disposal rates were decreased, and 
not increased, in pregnant compared with nonpregnant women, implying that significant amounts of glucose were not utilized by the fetal-placental unit in pregnant women (Ryan et al., 1985). Taken together, it is safe to assume that the glucose clearance curve represents the glucose uptake to the insulin-responsive tissues.

The basal NEFA concentrations before glucose infusion were 5.1-fold higher postpartum than prepartum, which could be explained by enhanced adipose tissue mobilization postpartum compared with the prepartum state. Plasma NEFA concentrations following glucose infusion decreased simultaneously to the increase in insulin concentrations both pre- and postpartum (Figure 2), which was also demonstrated in late-pregnant dairy cows following GTT (Schoenberg et al., 2012). The decrease in plasma NEFA concentrations following glucose infusion could also be explained by an acute homeostatic response to the elevated energy supply. In a similar manner, fat mobilization is suppressed rapidly by insulin; thus, plasma NEFA concentrations fall after a carbohydrate meal (Karpe et al., 2011). Furthermore, this could be partly explained by hepatic uptake of NEFA in response to the increased insulin concentrations, as it has been demonstrated in vitro that insulin increases the proportion of total oleate uptake by cultured calf hepatocytes (Zammit, 1996).

Several other studies examined the response to GTT in dairy cows in late pregnancy and early lactation. Similar to our study, the insulin response to GTT was higher prepartum and decreased postpartum (Bossaert et al., 2008; Kerestes et al., 2009); however, glucose clearance in response to GTT was either higher (Holtenius et al., 2003; Bossaert et al., 2008) or lower (Kerestes et al., 2009) postpartum compared with late pregnancy. The altered glucose clearance rate postpartum is in contrast to our results, as we observed similar glucose clearance in both periods. The discrepancy between the above studies and the current experiment could be mainly related to the timing of GTT relative to calving, which is a crucial factor, and to differences in breeds, genetic background, diet composition and management, or a combination of all of the above.

In the current study, basal plasma insulin concentrations and insulin response to GTT were lower postpartum than during late pregnancy. This can be explained by a reduction in food intake and perhaps lower pancreatic output toward parturition, as part of the homeorhetic adaptations occurring near calving in dairy cows to prioritize glucose supply to the mammary gland (Bell and Bauman, 1997). The decrease in circulating concentrations of insulin in the early postpartum period seems to be caused by a decrease in pancreatic output of insulin, rather than an increase in hepatic uptake, as was also demonstrated in Reynolds et al.
(2003), as pancreatic responsiveness to insulinotropic agents and plasma insulin levels are greatly depressed during early lactation (Lomax et al., 1979). Significant changes in insulin secretion during pregnancy were shown in various mammals; higher insulin production was observed in pregnant women (Lain and Catalano, 2006). Also, an increase in $\beta$ cell mass due to increased cell number and cellular hypertrophy was shown in pregnant compared with nonpregnant rats (Van Assche et al., 1980; Blondeau et al., 1999) and in humans (Van Assche et al., 1978). It was also demonstrated in beef cattle that the weight of the pancreas is $29 \%$ higher at $245 \mathrm{~d}$ than at $125 \mathrm{~d}$ in gestation (Meyer et al., 2010). Taken together, it is probable that a similar hyperplasia of the pancreas occurs in late-pregnant dairy cows, which would explain the elevated plasma insulin concentrations and the higher insulin response to GTT observed in our study in late-pregnant cows.

Interestingly, the response of the adipose tissues to GTT was not homogeneous, and differed between 2 subgroups of cows. Although the adipose tissues of LWL cows responded to insulin (as assessed by increased Akt phosphorylation) both pre- and postpartum, the adipose tissues of HWL cows were unresponsive at both time points (Figure 9a). Because only the HWL cows had unresponsive adipose tissues, we suggest that these cows showed a tissue-specific insulin resistance. This conclusion is supported by the fact that both groups exhibited similar increases in plasma insulin after GTT both pre- and postpartum, whereas only the HWL cows did not respond to this increase in the adipose tissues. Yet, we cannot rule out the option that the plasma insulin was not available to the adipose tissues of the HWL cows due to unidentified reasons (e.g., higher insulin degradation in the liver or changes in blood supply to these tissues). Bell and Bauman (1997) suggested that the multiple adaptations from late pregnancy to lactation are at least partly mediated by development of insulin resistance in maternal peripheral tissues. Our observations support a notion that the insulin resistance observed in the adipose tissue is cow dependent (HWL), as only the adipose tissues of HWL, but not LWL, cows were unresponsive to insulin in late pregnancy and in early lactation. Although we examined a small number of animals, it was found that these 2 subgroups of cows had several distinctive characteristics: the LWL lost little BW and BCS during the first weeks in lactation and produced more milk and FCM both in the present lactation and more FCM during the previous lactation (305 d) compared with the other subgroup of cows (HWL). The FCM production of the previous lactation is an indicator of the genetic potential of the cows, and indeed it was associated with the production in the present lacta- 
tion. The differences between the subgroups of cows were also supported by the numerically lower plasma concentrations of NEFA around calving in the LWL compared with the HWL cows. Our findings that the HWL cows produced less FCM and were unresponsive to insulin in the adipose tissue compared with LWL cows are not in accordance with Chagas et al. (2009), who stated that high-producing cows are more insulin resistant than low-producing cows. It should be noted that in Chagas et al. (2009), the difference in glucose fractional turnover rate was between 2 strains of cows that were with high or low production merit, rather than between cows from the same genetic background, which is the case in our study.

This distinct metabolic profile between cows infers that LWL cows may have had a specific genetic background that responded well to insulin and better repressed lipolysis in adipose tissue and, thus, lost less BW. However, as the subgroups in the present study contained a small number of animals, we prefer not to further speculate on the possible mechanisms of this phenomenon.

\section{CONCLUSIONS}

The main findings of the present study were that high-yielding dairy cows exhibited normal glucose clearance in response to GTT both pre- and postpartum, and the phosphorylation of IR and Akt in the liver and adipose tissues in response to GTT correlated with plasma insulin concentrations. Furthermore, the greater extent of insulin secretion prepartum nicely correlated with higher insulin action, as determined by the greater inhibition of the expression of hepatic gluconeogenic enzymes prepartum. Therefore, we conclude that highyielding dairy cows did not suffer from hepatic insulin resistance. Moreover, the observed positive correlations between insulin signaling and plasma insulin concentrations support our premise of homeorhetic adaption that enables the cow to prioritize the mammary gland over the insulin-responsive tissues and promote gluconeogenesis and lipolysis. Still, the phosphorylation of Akt in adipose tissue was low in HWL cows pre- and postpartum, implying adipose tissue-specific insulin resistance in these cows. Only the LWL cows had elevated Akt phosphorylation in adipose tissue, indicating that the lack of insulin responsiveness in adipose tissue was cow dependent (HWL) rather than period dependent. The subgroups of cows also differed in BW loss and milk yields, which may suggest that a part of the population of high-yielding dairy cows could have distinctive genetic characteristics that are related to adipose tissue-specific insulin resistance, but this subject requires further investigation with a large number of cows.

\section{REFERENCES}

Barthel, A., and D. Schmoll. 2003. Novel concepts in insulin regulation of hepatic gluconeogenesis. Am. J. Physiol. Endocrinol. Metab. 285:E685-E692.

Bauman, D. E., and J. M. Elliot. 1983. Control of nutrient partitioning in lactating ruminants. Pages 437-468 in Biochemistry of Lactation. T. B. Mepham, ed. Elsevier Science Publishers BV, Amsterdam, the Netherlands.

Bell, A. W. 1995. Regulation of organic nutrient metabolism during transition from late pregnancy to early lactation. J. Anim. Sci. 73:2804-2819.

Bell, A. W., and D. E. Bauman. 1997. Adaptations of glucose metabolism during pregnancy and lactation. J. Mammary Gland Biol. Neoplasia 2:265-278.

Blondeau, B., A. Garofano, P. Czernichow, and B. Bréant. 1999. Agedependent inability of the endocrine pancreas to adapt to pregnancy: A long-term consequence of perinatal malnutrition in the rat. Endocrinology 140:4208-4213.

Bossaert, P., J. L. Leroy, S. De Vliegher, and G. Opsomer. 2008. Interrelations between glucose-induced insulin response, metabolic indicators, and time of first ovulation in high-yielding dairy cows. J. Dairy Sci. 91:3363-3371.

Boura-Halfon, S., and Y. Zick. 2009. Phosphorylation of IRS proteins, insulin action, and insulin resistance. Am. J. Physiol. Endocrinol. Metab. 296:E581-E591.

Chagas, L. M., M. C. Lucy, P. J. Back, D. Blache, J. M. Lee, P. J. Gore, A. J. Sheahan, and J. R. Roche. 2009. Insulin resistance in divergent strains of Holstein-Friesian dairy cows offered fresh pasture and increasing amounts of concentrate in early lactation. J. Dairy Sci. 92:216-222.

Graber, M., S. Kohler, T. Kaufmann, M. G. Doherr, R. M. Bruckmaier, and H. A. van Dorland. 2010. A field study on characteristics and diversity of gene expression in the liver of dairy cows during the transition period. J. Dairy Sci. 93:5200-5215.

Gross, J., H. A. van Dorland, F. J. Schwarz, and R. M. Bruckmaier. 2011. Endocrine changes and liver mRNA abundance of somatotropic axis and insulin system constituents during negative energy balance at different stages of lactation in dairy cows. J. Dairy Sci. 94:3484-3494.

Holtenius, K., S. Agenäs, C. Delavaud, and Y. Chilliard. 2003. Effects of feeding intensity during the dry period. 2. Metabolic and hormonal responses. J. Dairy Sci. 86:883-891.

Kahn, C. R. 1978. Insulin resistance, insulin insensitivity, and insulin unresponsiveness: A necessary distinction. Metabolism 27:18931902.

Karpe, F., J. R. Dickmann, and K. N. Frayn. 2011. Fatty acids, obesity and insulin resistance: Time for a reevaluation. Diabetes 60:2441-2449.

Kerestes, M., V. Faigl, M. Kulcsár, O. Balogh, J. Földi, H. Fébel, Y. Chilliard, and G. Huszenicza. 2009. Periparturient insulin secretion and whole-body insulin responsiveness in dairy cows showing various forms of ketone pattern with or without puerperal metritis. Domest. Anim. Endocrinol. 37:250-261.

Laemmli, U. K. 1970. Cleavage of structural proteins during the assembly of the head of bacteriophage T4. Nature 227:680-685.

Lain, K. Y., and P. M. Catalano. 2006. Factors that affect maternal insulin resistance and modify fetal growth and body composition. Metab. Syndr. Relat. Disord. 4:91-100.

Lisowski, P., M. Pierzchała, J. Gościk, C. S. Pareek, and L. Zwierzchowski. 2008. Evaluation of reference genes for studies of gene expression in the bovine liver, kidney, pituitary, and thyroid. J. Appl. Genet. 49:367-372.

Locher, L. F., N. Meyer, E. M. Weber, J. Rehage, U. Meyer, S. Dänicke, and K. Huber. 2011. Hormone-sensitive lipase protein expression and extent of phosphorylation in subcutaneous and retroperi- 
toneal adipose tissues in the periparturient dairy cow. J. Dairy Sci. 94:4514-4523.

Lomax, M. A., G. D. Baird, C. B. Mallinson, and H. W. Symonds. 1979. Differences between lactating and non-lactating dairy cows in concentration and secretion rate of insulin. Biochem. J. 180:281-289

Meyer, A. M., J. J. Reed, K. A. Vonnahme, S. A. Soto-Navarro, L. P. Reynolds, S. P. Ford, B. W. Hess, and J. S. Caton. 2010. Effects of stage of gestation and nutrient restriction during early to mid-gestation on maternal and fetal visceral organ mass and indices of jejunal growth and vascularity in beef cows. J. Anim. Sci. 88:2410-2424.

NRC. 1989. Nutrient Requirements of Dairy Cattle. 6th rev. ed. Natl. Acad. Sci., Washington, DC.

Opsomer, G., T. Wensing, H. Laevens, M. Coryn, and A. de Kruif. 1999. Insulin resistance: The link between metabolic disorders and cystic ovarian disease in high yielding dairy cows? Anim. Reprod. Sci. 56:211-222.

Reynolds, C. K., P. C. Aikman, B. Lupoli, D. J. Humphries, and D. E. Beever. 2003. Splanchnic metabolism of dairy cows during the transition from late gestation through early lactation. J. Dairy Sci. 86:1201-1217.

Ryan, E. A., M. J. O'Sullivan, and J. S. Skyler. 1985. Insulin action during pregnancy. Studies with the euglycemic clamp technique. Diabetes 34:380-389.

Saltiel, A. R., and C. R. Kahn. 2001. Insulin signalling and the regulation of glucose and lipid metabolism. Nature 414:799-806.

Samuel, V. T., and G. I. Shulman. 2012. Mechanisms for insulin resistance: Common threads and missing links. Cell 148:852-871.
Schoenberg, K. M., R. M. Ehrhardt, and T. R. Overton. 2012. Effects of plane of nutrition and feed deprivation on insulin responses in dairy cattle during late gestation. J. Dairy Sci. 95:670-682.

Sevillano, J., J. de Castro, C. Bocos, E. Herrera, and M. P. Ramos. 2007. Role of insulin receptor substrate- 1 serine 307 phosphorylation and adiponectin in adipose tissue insulin resistance in late pregnancy. Endocrinology 148:5933-5942.

Van Assche, F. A., L. Aerts, and F. De Prins. 1978. A morphological study of the endocrine pancreas in human pregnancy. Br. J. Obstet. Gynaecol. 85:818-820.

Van Assche, F. A., W. Gepts, and L. Aerts. 1980. Immunocytochemical study of the endocrine pancreas in the rat during normal pregnancy and during experimental diabetic pregnancy. Diabetologia 18:487-491.

White, H. M., S. L. Koser, and S. S. Donkin. 2011. Bovine pyruvate carboxylase $5^{\prime}$ untranslated region variant expression during transition to lactation and feed restriction in dairy cows. J. Anim. Sci 89:1881-1892.

Wilson, L. A., S. E. Mills, E. Finley, E. Kilgour, P. J. Buttery, and R. G. Vernon. 1996. Effect of lactation on insulin signal transduction in sheep adipose tissue and skeletal muscle. J. Endocrinol. 151:469-480.

Zammit, V. A. 1996. Role of insulin in hepatic fatty acid partitioning: Emerging concepts. Biochem. J. 314:1-14.

Zick, Y. 2001. Insulin resistance: A phosphorylation-based uncoupling of insulin signaling. Trends Cell Biol. 11:437-441. 